\title{
The Relationship Between Social Change Involvement and Education
}

\author{
Michelle S. Brown \\ Walden University \\ Beate Baltes \\ Walden University
}

\begin{abstract}
Positive social change is part of Walden University's mission. As such, the institution sponsored the Social Change Impact Report, which includes data from three online surveys that investigated participants' experiences with social change because factors related to involvement in social action to improve the lives of individuals and communities are not fully known. Data were collected from the Social Change Impact Report to examine the relationship between the level of education an individual has achieved and how they rate the importance of and the involvement in positive social change activities. Results of chi square and analysis of variance indicated significant relationships between variables and an apparent upward trend in perceptions of and self-reported involvement in social change activities as level of education increases.
\end{abstract}

Keywords: social change, social change involvement, level of education

\section{Introduction}

The role of education as an agent of social change has been discussed for decades by many philosophers and educators. The discussion was formalized with the advent of critical theory by the Frankfurt School (Corradetti, n.d.) and was further interpreted with applications towards education by Paulo Freire (1970) in his seminal text Pedagogy of the Oppressed. This research focused specifically on individual's levels of education and the relationship with involvement in social change activities. Specifically examined were how individuals rate the importance of and the involvement in positive social change activities.

\section{Background}

The emphasis of Paulo Freire's (1970) deliberations was on how education allows the oppressed to regain their sense of humanity and escape their role of the oppressed. Nelson Mandela (2003) stated that "education is the most powerful weapon which you can use to change the world" (p. 6), whereas Jacques Delors (1996) wrote that education is "an indispensable asset in its attempt to attain the ideals of peace, freedom and social justice" (p. 11). More recently the director general of the United Nations Educational, Scientific, and Cultural Organization (UNESCO, 2015), Irina Bokova wrote:

There is no more powerful transformative force than education-to promote human rights and dignity, to eradicate poverty and deepen sustainability, to build a better future for all, founded on equal rights and social justice, respect for cultural diversity, and international 
solidarity and shared responsibility, all of which are fundamental aspects of our common humanity. (p. 4)

There is consensus among leaders that education promotes not only the quality of life but also social equity. However, education might not only be the outcome of social change but might also be the reason for social change. Education makes a person aware of the social inequities and inequalities, most likely creating a desire for social change that might not have existed before the educational endeavor. With the knowledge of inequities and social ills as well as the desire to change the status quo, it can be assumed that a person is much more likely to attempt to change that status quo. Nevertheless, social change does not mean a drastic or immediate departure from the status quo. Merrill and Eldredge (1952) proposed that "social change means that large number of persons are engaging in activities that differ from those which they or their immediate forefathers engaged in some time before" (p. 512), which makes social change a phenomenon that can happen at any time at any place.

Walden University's mission of social change encourages all members of the academic community to strive for positive social change. For example, the Richard W. Riley College of Education and Leadership (Walden University, Riley College of Education, 2017, Our Mission section, para. 1) prepares its students to "inspire, influence, and impact their diverse communities by helping to meet the challenges and opportunities of education worldwide", the School of Public Policy and Administration (Walden University, School of Public Policy and Administration, 2017) teaches its students about democratic processes to eventually work toward positive social change, and the School of Nursing (Walden University, School of Nursing, 2017) trains its nursing professionals in nursing knowledge in order to transform society. The Walden University academic community celebrates everybody's accomplishments and supports efforts with recognition, encouragement, and even financial resources. The combined accomplishment of Walden University students, staff, and faculty is impressive. To understand such combined social change accomplishments by its students and faculty, all having or pursuing advanced degrees, Walden University collected data on Americans' perceptions of and self-reported involvement in social change activities to learn if the level of involvement differs by educational level. In other words, as much as education is considered essential for positive social change, it is not sufficiently established if the level of education, reaching from grade school to doctoral degrees, is associated with the level of importance that individuals assign to involvement in positive social change as well as their actual involvement in social change activities.

The possible transformations that can occur through education are many, but positive social change is a commonly cited ideal. As noted in the publication Rethinking Education: Towards a Global Common Good? (UNESCO, 2015), the authors noted that,

There is no more powerful transformative force than education-to promote human rights and dignity, to eradicate poverty and deepen sustainability, to build a better future for all, founded on equal rights and social justice, respect for cultural diversity, and international solidarity and shared responsibility, all of which are fundamental aspects of our common humanity. (p. 4)

Viewing education through this lens established the basis for this study. 


\section{Purpose of the Study}

The purpose of this study was to explore the relationship between the level of education an individual has achieved and how they rate the importance of and involvement in positive social change activities. Using data from Walden University's (2011) Social Change Impact Report (SCIR), Americans' perceptions of and self-reported involvement in social change activities were examined by their level of education. The 2011 SCIR was examined for the survey items that measured the (a) highest level of education completed, (b) importance of involvement in social change, and (c) level of involvement in social change activities in the past 12 months. The research questions guiding this investigation were

Research Question 1: What is the relationship between the level of importance individuals assign to involvement in positive social change and their level of education?

Research Question 2: What is the relationship between participants' social change involvement score and their level of education?

\section{Method and Procedures}

\section{Instrumentation}

The SCIR Dataset is a Walden-owned database of research results generated from three online surveys about social change that were conducted by Harris Interactive on behalf of Walden University in 2011 and 2012. The surveys investigate U.S. and international participants' views on and experiences with positive social change and/or social action-more specifically, involvement in activities that make improvements in the lives of individuals and communities both locally and around the world. The 2011 SCIR was examined for the following survey items:

- Q437: What is the highest level of education you have completed or the highest degree you have received? (scale)

- Q700: How important is it to you personally to be involved in positive social change? (scale)

- Q731: Social Change Involvement Score (composite score of 13 items): During the past 12 months, how often have you done each of the following activities to engage in positive social change?

- Educated others about a cause or issue

- Participated in volunteer work or service

- Expressed an opinion on a positive social change issue by writing an email or letter to the editor of a newspaper or magazine, or calling a live radio or TV show

- Expressed an opinion on a positive social change issue by posting a comment on a blog or other website

- Wrote to or called any politician at the local, state or federal level

- Attended a political rally, speech or protest of any kind

- Signed an online or written petition

- Donated money, goods, or services

- Joined or created a group on a social networking site (e.g., Facebook, Twitter, LinkedIn, Jumo, etc.) that was dedicated to a positive social change issue

- Fundraised for a cause 
- Organized or united friends or neighbors to work together for a particular cause or issue

- Texted to make donations, voted, organized a demonstration, etc., related to a specific cause or issue

- Provided leadership skills to a cause or organization related to positive social change (e.g., serving on a board or committee, etc.)

\section{Study Participants}

The survey for the SCIR was conducted online within the United States by Harris Interactive on behalf of Walden University between March 16th and March 24th, 2011. Surveys were conducted among 2,148 U.S. residents of the age 18 or older. Data were weighted to be representative of the U.S. general population using targets obtained from the U.S. Census. Figures for age, sex, race/ethnicity, education, region and household income were weighted where necessary to bring them into line with their actual proportions in the population.

\section{Study Design and Data Analysis}

To examine the association between the level of importance individuals assign to involvement in positive social change and their level of education, and level of education and positive social change activity, a descriptive comparative design was used. The independent variable for both analyses was the respondent's level of education and was Q437 in the data file. The original response categories included 14 levels, as presented in Table 1.

Table 1. Frequencies for Original Q437: What Is the Highest Level of Education You Have Completed or the Highest Degree You Have Received?

\begin{tabular}{lcccc}
\hline Level of Education & Frequency & Percent & $\begin{array}{c}\text { Valid } \\
\text { Percent }\end{array}$ & $\begin{array}{c}\text { Cumulative } \\
\text { Percent }\end{array}$ \\
\hline Less than high school & 19 & .9 & .9 & .9 \\
Completed some high school & 82 & 3.8 & 3.8 & 4.7 \\
Completed high school & 488 & 22.7 & 22.7 & 27.4 \\
Completed some college & 566 & 26.4 & 26.4 & 53.8 \\
Completed College & 457 & 21.3 & 21.3 & 75.1 \\
Completed some graduate school & 95 & 4.4 & 4.4 & 79.5 \\
Completed graduate school & 105 & 4.9 & 4.9 & 84.4 \\
Associate Degree & 202 & 9.4 & 9.4 & 93.8 \\
MA, MS, MFA & 57 & 2.6 & 2.6 & 96.4 \\
MBA & 23 & 1.1 & 1.1 & 97.5 \\
PhD, PsyD, or other academic & 20 & .9 & .9 & 98.4 \\
doctorate & & & & \\
JD & 6 & .3 & .3 & 98.7 \\
MD & 8 & .4 & .4 & 99.1 \\
Other graduate or professional degree & 20 & .9 & .9 & 100.0 \\
Total & 2148 & 100.0 & 100.0 & \\
\hline
\end{tabular}

For analysis, the education variable was recoded into a factor with five levels-high school or less, some college, associate's degree, college degree/some grad school, masters or doctorate. Table 2 presents the frequencies of responses for the recoded highest level of education variable. The recoded, five-level factor was utilized as the independent variable for both analyses. 
Table 2. Frequencies for Recoded Q437: What Is the Highest Level of Education You Have Completed or the Highest Degree You Have Received?

\begin{tabular}{lcccc}
\hline Level of Education & Frequency & Percent & $\begin{array}{c}\text { Valid } \\
\text { Percent }\end{array}$ & $\begin{array}{c}\text { Cumulative } \\
\text { Percent }\end{array}$ \\
\hline High school or less & 589 & 27.4 & 27.4 & 27.4 \\
Some college & 566 & 26.4 & 26.4 & 53.8 \\
Associates degree & 202 & 9.4 & 9.4 & 63.2 \\
College degree/some grad school & 552 & 25.7 & 25.7 & 88.9 \\
Masters or doctorate & 239 & 11.1 & 11.1 & 100.0 \\
Total & 2148 & 100.0 & 100.0 & \\
\hline
\end{tabular}

The dependent variable for the first analysis was the level of importance individuals assign to their personal involvement in positive social change. Table 3 presents the frequencies and percentages of response for this variable.

Table 3. Frequencies for Q700: How Important Is It to You Personally to Be Involved in Positive Social Change?

\begin{tabular}{lcccc}
\hline Level of Importance & Frequency & Percent & Valid Percent & $\begin{array}{c}\text { Cumulative } \\
\text { Percent }\end{array}$ \\
\hline Not at all important & 90 & 4.2 & 4.2 & 4.2 \\
Not too important & 395 & 18.4 & 18.4 & 22.6 \\
Somewhat important & 1068 & 49.7 & 49.7 & 72.3 \\
Very important & 596 & 27.7 & 27.7 & 100.0 \\
Total & 2148 & 100.0 & 100.0 & \\
\hline
\end{tabular}

The dependent variable for the second analysis was a composite score comprised of the 13 items measuring social change activity engagement. Total composite scores ranged from 13 to 65 and the mean score for the sample of respondents was $M=27.62(S D=10.75)$. Descriptive statistics for the dependent variable by level of education are presented in Table 4.

Table 4. Mean Social Change Involvement Score by Level of Education

\begin{tabular}{lccc}
\hline Level of Education & $M$ & $S D$ & $N$ \\
\hline High school or less & 23.56 & 9.378 & 590 \\
Some college & 28.30 & 10.352 & 582 \\
Associates degree & 26.93 & 10.897 & 196 \\
College degree/some grad school & 29.88 & 10.730 & 533 \\
Masters or doctorate & 32.25 & 11.620 & 202 \\
Total & 27.62 & 10.746 & 2,103 \\
\hline
\end{tabular}




\section{Results}

To examine the association between the level of importance individuals assign to involvement in positive social change and their level of education, a $4 \times 5$ cross-tabulation with chi square analysis was conducted. Based on the results, there is a statistically significant association between the importance one gives to involvement in positive social change and their level of education, Pearson $\chi^{2}(12, N=2,146)=88.61, p<.001$, Cramer's $V=.117$. As represented in Table 5 , the proportions of each level of education group who reported involvement in positive social change as either somewhat or very important were $.70, .79, .69, .81$, and .89 , respectively. It appears as level of education increases, the importance given to personal involvement in positive social change also increases; however, the level of education group representing associates degrees appeared to not follow the pattern and tended to view personal involvement as less important.

Table 5. Q700: How Important Is It to You Personally to Be Involved in Positive Social Change? By Level of Education Cross-Tabulation Results

\begin{tabular}{|c|c|c|c|c|c|c|}
\hline \multirow[b]{2}{*}{ Level of Importance } & \multicolumn{5}{|c|}{ Level of Education } & \multirow[b]{2}{*}{ Total } \\
\hline & $\begin{array}{l}\text { High School } \\
\text { or Less }\end{array}$ & $\begin{array}{l}\text { Some } \\
\text { College }\end{array}$ & $\begin{array}{l}\text { Associates } \\
\text { Degree }\end{array}$ & $\begin{array}{c}\text { College } \\
\text { Degree/Some } \\
\text { Grad School }\end{array}$ & $\begin{array}{l}\text { Masters or } \\
\text { Doctorate }\end{array}$ & \\
\hline \multicolumn{7}{|l|}{ Not at all important } \\
\hline$n$ & 39 & 15 & 7 & 25 & 3 & 890 \\
\hline $\begin{array}{l}\% \text { Within level of } \\
\text { education }\end{array}$ & $6.6 \%$ & $2.7 \%$ & $3.5 \%$ & $4.5 \%$ & $1.3 \%$ & $4.1 \%$ \\
\hline$\%$ of Total & $1.8 \%$ & $0.7 \%$ & $0.3 \%$ & $1.2 \%$ & $0.1 \%$ & $4.1 \%$ \\
\hline \multicolumn{7}{|l|}{ Not too important } \\
\hline$n$ & 136 & 101 & 55 & 79 & 24 & 395 \\
\hline $\begin{array}{l}\% \text { Within level of } \\
\text { education }\end{array}$ & $23.1 \%$ & $17.9 \%$ & $27.2 \%$ & $14.3 \%$ & $10.0 \%$ & $18.4 \%$ \\
\hline$\%$ of Total & $6.3 \%$ & $4.7 \%$ & $2.6 \%$ & $3.7 \%$ & $1.1 \%$ & $18.4 \%$ \\
\hline \multicolumn{7}{|l|}{ Somewhat important } \\
\hline$n$ & 303 & 294 & 93 & 263 & 114 & 1067 \\
\hline $\begin{array}{l}\% \text { Within level of } \\
\text { education }\end{array}$ & $51.4 \%$ & $52.0 \%$ & $46.0 \%$ & $47.7 \%$ & $47.7 \%$ & $49.7 \%$ \\
\hline$\%$ of Total & $14.1 \%$ & $13.7 \%$ & $4.3 \%$ & $12.3 \%$ & $5.3 \%$ & $49.7 \%$ \\
\hline \multicolumn{7}{|l|}{ Very important } \\
\hline$n$ & 111 & 155 & 47 & 184 & 98 & 595 \\
\hline $\begin{array}{l}\% \text { Within level of } \\
\text { education }\end{array}$ & $18.8 \%$ & $27.4 \%$ & $23.3 \%$ & $33.4 \%$ & $41.0 \%$ & $27.7 \%$ \\
\hline$\%$ of Total & $5.2 \%$ & $7.2 \%$ & $2.2 \%$ & $8.6 \%$ & $4.6 \%$ & $27.7 \%$ \\
\hline \multicolumn{7}{|l|}{ Total } \\
\hline$n$ & 589 & 565 & 202 & 551 & 239 & 2146 \\
\hline $\begin{array}{l}\% \text { Within level of } \\
\text { education }\end{array}$ & $100.0 \%$ & $100.0 \%$ & $100.0 \%$ & $100.0 \%$ & $100.0 \%$ & $100.0 \%$ \\
\hline$\%$ of Total & $27.4 \%$ & $26.3 \%$ & $9.4 \%$ & $25.7 \%$ & $11.1 \%$ & $100.0 \%$ \\
\hline
\end{tabular}

To examine the relationship between the reported level of social change involvement of individuals within the past 12 months (social change involvement score) and their level of education, a one-way analysis of variance was conducted with level of education as the independent variable and the social change involvement scores as the numeric dependent variable. The analysis of variance was 
significant, $F(4,2098)=39.81, p<.001$ (Table 6). The strength of the relationship between level of education and the social change involvement scores, as assessed by $\eta^{2}$, was moderate, with the education factor accounting for $7 \%$ of the variance of the dependent variable.

Table 6. Analysis of Variance Results for Differences in Social Change Involvement Score by Education Group

\begin{tabular}{|c|c|c|c|c|c|c|}
\hline Source & $\begin{array}{c}\text { Type III Sum of } \\
\text { Squares }\end{array}$ & $d f$ & Mean Square & $F$ & $p$ & $\eta^{2} \mathrm{p}$ \\
\hline Corrected model & $17,122.782^{\mathrm{a}}$ & 4 & $4,280.696$ & 39.809 & .000 & .071 \\
\hline Intercept & $1,294,443.093$ & 1 & $1294,443.093$ & $12,037.879$ & .000 & .852 \\
\hline Level of education & $17,122.782$ & 4 & $4,280.696$ & 39.809 & .000 & .071 \\
\hline Error & $225,599.683$ & 2,098 & 107.531 & & & \\
\hline Total & $1,847,255.000$ & 2,103 & & & & \\
\hline Corrected total & $242,722.465$ & 2,102 & & & & \\
\hline
\end{tabular}

a $R^{2}=.071$ (adjusted $R^{2}=.069$ ).

Follow-up tests were conducted to evaluate pairwise differences among the group means. Based on the Levene's test of equality of error variances, $F(4,2098)=4.905, p<.001$, the Dunnett's $C$ test, a test that does not assume equal variances among the groups, was used.

The means, by level of education group, along with the $95 \%$ confidence interval for the means, are presented in Table 7. The results of the Dunnett's $C$ post hoc test are presented in Table 8. As presented in these tables, there appears to be a general, upward trend in self-report social change involvement as level of education increases.

The lowest mean social change involvement score was reported for respondents who earned a high school diploma or less $(M=25.56)$. The greatest mean social change involvement score was reported by respondents with a masters or doctorate. Based on the post hoc analysis, the high school group mean was significantly lower than all other groups. The masters/doctorate group mean was significantly higher than all groups mean scores other than those with a college degree. Respondents with some college reported involvement scores significantly greater than those in the high school or less group and significantly lower than those with a masters/doctorate.

Table 7. 95\% Confidence Interval for Means of Social Change Involvement Score by Level of Education

\begin{tabular}{lccc}
\hline Level of Education & $M$ & $S E$ & $95 \%$ Confidence Interval \\
\hline High school or less & 23.563 & .427 & {$[22.725,24.400]$} \\
Some college & 28.296 & .430 & {$[27.453,29.138]$} \\
Associates degree & 26.934 & .741 & {$[25.481,28.386]$} \\
College degree/some grad school & 29.878 & .449 & {$[28.997,30.759]$} \\
Masters or doctorate & 32.252 & .730 & {$[30.822,33.683]$} \\
\hline
\end{tabular}


Table 8. Dunnett C Post Hoc Test for Mean Differences in Social Change Involvement Score by Level of Education Groups

\begin{tabular}{|c|c|c|c|c|}
\hline (I) Level of Education & (J) Level of Education & $\begin{array}{l}M_{\text {difference }} \\
(\mathrm{I}-\mathrm{J})\end{array}$ & $S E$ & $\begin{array}{l}95 \% \text { Confidence } \\
\text { Interval }\end{array}$ \\
\hline \multirow[t]{4}{*}{ High school or less } & Some college & $-4.73^{*}$ & .577 & {$[-6.31,-3.15]$} \\
\hline & Associates degree & $-3.37^{*}$ & .869 & {$[-5.76,-.98]$} \\
\hline & $\begin{array}{l}\text { College degree/some grad } \\
\text { school }\end{array}$ & $-6.32^{*}$ & .604 & {$[-7.97,-4.66]$} \\
\hline & Masters or doctorate & $-8.69^{*}$ & .904 & {$[-11.18,-6.20]$} \\
\hline \multirow[t]{4}{*}{ Some college } & High school or less & $4.73^{*}$ & .577 & {$[3.15,6.31]$} \\
\hline & Associates degree & 1.36 & .889 & {$[-1.08,3.81]$} \\
\hline & $\begin{array}{l}\text { College degree/some grad } \\
\text { school }\end{array}$ & -1.58 & .633 & {$[-3.31, .15]$} \\
\hline & Masters or doctorate & $-3.96^{*}$ & .923 & {$[-6.50,-1.42]$} \\
\hline \multirow[t]{5}{*}{ Associates degree } & High school or less & $3.37^{*}$ & .869 & {$[.98,5.76]$} \\
\hline & Some college & -1.36 & .889 & {$[-3.81,1.08]$} \\
\hline & $\begin{array}{l}\text { College degree/some grad } \\
\text { school }\end{array}$ & $-2.94^{*}$ & .907 & {$[-5.44,-.45]$} \\
\hline & Masters or doctorate & $-5.32^{*}$ & 1.129 & {$[-8.43,-2.21]$} \\
\hline & High school or less & $6.32^{*}$ & .604 & {$[4.66,7.97]$} \\
\hline \multirow{3}{*}{$\begin{array}{l}\text { College degree/ } \\
\text { some grad school }\end{array}$} & Some college & 1.58 & .633 & {$[-.15,3.31]$} \\
\hline & Associates degree & $2.94^{*}$ & .907 & {$[.45,5.44]$} \\
\hline & Masters or doctorate & -2.37 & .940 & {$[-4.96, .21]$} \\
\hline \multirow[t]{4}{*}{ Masters or doctorate } & High school or less & $8.69^{*}$ & .904 & {$[6.20,11.18]$} \\
\hline & Some college & $3.96^{*}$ & .923 & {$[1.42,6.50]$} \\
\hline & Associates degree & $5.32^{*}$ & 1.129 & {$[2.21,8.43]$} \\
\hline & $\begin{array}{l}\text { College degree/some grad } \\
\text { school }\end{array}$ & 2.37 & .940 & {$[-.21,4.96]$} \\
\hline
\end{tabular}

* Statistically significant.

\section{Discussion}

The number of students in higher education is growing steadily. The National Center for Education Statistics (n.d.) calculated a 17\% enrollment increase between 2004 and 2014. In the Digest for Education Statistics, over 20 million students are reported in college for the year 2015 (National Center for Education Statistics, 2016). For the students, an advanced degree can mean higher wages and better health (Schanzenbach, Bauer, \& Breitwieser, 2017) and the economy benefits with lower rates of unemployment (Greenstone \& Looney, 2011) and increased America's competitiveness (Eberly \& Martin, 2012).

Not only is the knowledge and skills of college students important but also their attitude toward their role in society. Ireland's president spoke at the European University Association's annual conference challenging universities to enable their students to develop the intellectual tools that are necessary to, for example, eliminate poverty, resolve climate change and sustainability, and find solutions for conflict and displacements. In short, universities need to educate their students to be 
active social change agents. And they do. The National Task Force on Civic Learning and Democratic Engagement (2012) reported that $70 \%$ of all college students participated in some form of volunteering, community service, or service learning during their time in college. Approximately half of college students indicated on the National Survey of Student Engagement (2010) that they participate in service learning activities as part of their class work.

Walden University's scholar-practitioner model supports the efforts of universities to install social change ideals in students. Students' knowledge and research results are applied to real-world situations, effecting immediate positive social changes in the students' community. Potential dissemination of research results, for example through projects created by the students, are a form of advocacy on behalf of the community that needs to be supported the most (less privileged).

The results of this study demonstrate a significant relationship between degree level, meaning also time spent in education, and the importance they assign to involvement in positive social change as well as their reported level of social change involvement. With the increase in students and the number of students that are pursuing college degrees as well as the efforts by most universities to help students develop an ethical responsibility, it can be assumed that more humans are actively engaged in making the world a better place for all.

It is recommended to further investigate how education might have implications for positive social change. A qualitative investigation of students' experiences in the education process and the connection with their world views and social change action would provide additional depth of findings. In addition, an examination of specific student populations would expand the understanding of the relationship between education and social change work. Continued research in this area would benefit not only the field of education, but the world as well, as increased educational opportunities may promote solidarity and a shared responsibility for sustaining our common humanity.

\section{References}

Corradetti, C. (n.d.). The Frankfurt school and critical theory. Internet Encyclopedia of Philosophy. Retrieved from http://www.iep.dutm.edu/frankfur/

Delors, J. (1996). Learning: The treasure within. Retrieved from http://unesdoc.unesco.org/images/0010/001095/109590eo.pdf

Eberly, J., \& Martin, C. (2012). The economic case for higher education. Retrieved from https://www.treasury.gov/connect/blog/Pages/economics-of-higher-education.aspx

Freire, P. (1970). Pedagogy of the oppressed. New York NY: Seabury.

Greenstone, M., \& Looney, A. (2011). The Hamilton project: Have earnings actually declined? Retrieved from http://www.hamiltonproject.org/assets/legacy/files/downloads_and_links/02_jobs_earnings.pdf

Mandela, N. (2003, July 16). Lightening your way to a better future [Speech]. Retrieved from http://db.nelsonmandela.org/speeches/pub_view.asp?pg=item\&ItemID=NMS909

Merrill, F. E., \& Eldredge, H. W. (1952). Culture and society: An introduction to sociology. Upper Saddle River, NJ: Prentice-Hall.

National Center for Education Statistics. (n.d.). Fast facts. Retrieved from https://nces.ed.gov/fastfacts/display.asp?id=98 
National Center for Education Statistics. (2016). Digest of education statistics (51st ed.). Retrieved from https://nces.ed.gov/pubsearch/pubsinfo.asp?pubid=2016014

National Survey of Student Engagement. (2010). NSSE 2010 Grand frequencies by mayor, first-year students and seniors. Bloomington, IN: Indiana University Center for Postsecondary Research.

National Task Force on Civic Learning and Democratic Engagement. (2012). A crucible moment: College learning and democracy's future. Washington, DC: Association of American Colleges and Universities.

Schanzenbach, D. W., Bauer, L., \& Breitwieser, A. (2017). Eight economic facts on higher education. Retrieved from https://www.brookings.edu/research/eight-economic-facts-on-highereducation/

United Nations Educational, Scientific, and Cultural Organization (UNESCO). (2015). Rethinking education: Towards a global common good? Retrieved from http://www.unesco.org/fileadmin/MULTIMEDIA/FIELD/Cairo/images/RethinkingEducation. $\mathrm{pdf}$

Walden University. (2011). 2011 Social change impact report. Retrieved from https://www.waldenu.edu/-/media/Walden/files/about-walden/scir/2011/walden-universitysocial-change-impact-report-2011.pdf?la=en

Walden University, Riley College of Education. (2017). Our mission. Retrieved from https://www.waldenu.edu/about/colleges-schools/riley-college-of-education

Walden University, School of Nursing. (2017). Our mission. Retrieved from https://www.waldenu.edu/about/colleges-schools/college-of-health-sciences/school-of-nursing

Walden University, School of Public Policy and Administration. (2017). Our mission. Retrieved from https://www.waldenu.edu/connect/events-and-webinars

The Journal of Social Change, sponsored by Walden University, welcomes manuscripts focusing on interdisciplinary research in social change that improves the human condition and moves people, groups, organizations, cultures, and society toward a more positive future.

Walden University Publishing: http://www.publishing.waldenu.edu 